\title{
Detection and Quantification of Spongospora subterranea Sporosori in Soil by Quantitative Real-Time PCR
}

\author{
Ipsita Mallik, ${ }^{1}$ Ana Cristina Fulladolsa, ${ }^{2}$ S. K. R. Yellareddygari, ${ }^{1}{ }_{\text {Francisco G. Bittara, }}{ }^{1}$ Amy O. Charkowski, ${ }^{2}$ \\ and Neil C. Gudmestad ${ }^{1, \dagger}$ \\ ${ }^{1}$ Department of Plant Pathology, North Dakota State University, Fargo, ND 58108 \\ ${ }^{2}$ Bioagricultural Sciences and Pest Management, Colorado State University, Fort Collins, CO 80523
}

\begin{abstract}
Powdery scab on potato tubers is caused by the obligate soilborne biotroph Spongospora subterranea and is known to cause substantial losses in potato production. The pathogen also infects roots of susceptible hosts, forming galls which can negatively affect root function. S. subterranea is also the vector of Potato mop-top virus, which causes a tuber necrosis disease that can, depending on temperature and cultivar, render potato tubers unmarketable. In this study, we adapted a published protocol to develop a sensitive and robust quantitative real-time PCR (qPCR) assay using specific primers and probes for detecting and quantifying $S$. subterranea sporosori in soil types that differ in physical properties, including organic matter content and soil pH. For the first time, an external control was utilized and applied directly to the soil prior to DNA extraction, which facilitated normalization of $S$. subterranea sporosori soil levels from sample to sample. The duplex qPCR protocol was demonstrated to be highly

sensitive, capable of detecting and quantifying as few as 1 sporosorus/g of soil, with consistently high qPCR efficiency and the coefficient of determination $\left(R^{2}\right)$ values ranging from 94 to $99 \%$ and 0.98 to 0.99 , respectively. The protocol was successfully implemented in enumerating $S$. subterranea sporosori in naturally infested field soil collected from several states and in artificial potting mixes with high organic matter content ranging from 64 to $71 \%$. The qPCR method developed can be useful for potato growers to avoid agricultural soils highly infested with $S$. subterranea and in the development of risk assessment models in the future that incorporate cultivar susceptibility to powdery scab and soil infestation levels.

Keywords: disease management, disease warning systems, epidemiology, external control, fungi, qPCR, Spongospora subterranea quantification soil, vegetables
\end{abstract}

The demand for high-quality potato tubers has increased substantially for commercial potato producers in the United States which have contributed to shorter rotation periods and reduced crop diversity. This adversely affects the physical and biological properties of the soil. Additionally, an increase in soilborne diseases in potato results in the decline of productivity (Grandy et al. 2002). Among the many soilborne diseases affecting potato, common scab (Streptomyces spp.), powdery scab (Spongospora subterranea (Wallr.) Lagerh.) (Wallroth 1842), black dot (Colletotrichum coccodes Wallr.), Verticillium wilt (Verticillium dahliae Kleb.), black scurf (Rhizoctonia solani Kühn), and white mold (Sclerotinia sclerotiorum (Lib.) de Bary) can cause persistent and recurring diseases of potato, resulting in economic losses.

Spongospora subterranea is a biotrophic pathogen that has a biphasic life cycle, allowing it to persist in soil with the production of resting spore aggregates (sporosori) and also multiplying through the formation of short-lived zoospores in the host when environmental conditions are favorable (Harrison et al. 1997; Merz 2008). At the present time, S. subterranea cannot be cultured in vitro. The scablike lesions on tubers are considered a serious blemish disease and substantially reduce tuber quality and marketability. Symptoms of the disease include galls on roots and scab-like eruptions on the surface of tubers which contain masses of sporosori which, in turn, contributes to the increase of soil inoculum (Brierley et al. 2009; Christ 2001).

${ }^{\dagger}$ Corresponding author: N. C. Gudmestad; Neil.Gudmestad@ndsu.edu

Funding: This study was funded, in part, by research funding from the USDA-NIFA-SCRI program, grant number 2014-51181-22373.

The author(s) declare no conflict of interest.

Accepted for publication 16 July 2019.

(C) 2019 The American Phytopathological Society
The powdery scab pathogen is considered to be both seedborne and soilborne, and both sources of inoculum can by themselves lead to the development of disease on progeny tubers (de Nazareno and Boschetto 2002; Falloon et al. 1996; Letham et al. 1989; Merz et al. 2006). The pathogen is dispersed to noninfested soils via infected seed tubers with the subsequent increase of inoculum levels in soils (Merz and Falloon 2009). However, disease development is highly dependent on environmental conditions being favorable for infection and powdery scab development. Several studies have demonstrated that disease incidence and severity are significantly lower when temperature or soil moisture are not conducive for disease development (Christ and Weidner 1988; Domfeh and Gudmestad 2016; Nakayama et al. 2007).

S. subterranea is also the vector for the Potato mop-top virus (PMTV), which causes internal necrosis of potato tubers. (Arif et al. 1995; Harrison et al. 1997; Jones and Harrison 1969; Neuhauser et al. 2010). S. subterranea sporosori are resistant to environmental stresses and cause disease in both temperate and hot climates (Harrison et al. 1997; Merz and Falloon 2009; Wale 2000). The sporosori can also persist and survive in soil for long periods of time (Braselton 2001; Sparrow et al. 2015). Additionally, S. subterranea is known to infect several solanaceous and nonsolanaceous species, making it difficult to control (Falloon 2008; Merz and Falloon 2009). Neuhauser et al. 2014; Qu and Christ 2006). Currently, there are very few measures to control this pathogen, with no effective chemical treatment available. It has been reported, however, that $S$. subterranea soil populations can be reduced significantly when soil is fumigated with chloropicrin (Bittara et al. 2017). Unfortunately, the net result was an increase in disease incidence, with both root gall formation and tuber scab lesion development.

One of the early constraints in the development of effective disease management strategies for soilborne diseases of potato was the lack of a rapid and effective method for detection and quantification of pathogens in soil. Identification of soilborne pathogens has been traditionally accomplished with symptom diagnosis or selective media, often accompanied by the examination of spores or other morphological features; bait plant bioassays; and biochemical, chemical, and 
immunological analysis (Carnegie et al. 2003; Merz 1989; Singleton et al. 1992).

Conventional PCR developed in the mid-1980s enhanced a rapid and specific detection of pathogen DNA at a very low concentration. This technique essentially analyzes the end-point product in an amplification process and cannot be used to quantify the pathogen level. However, a competitive conventional PCR assay exists in which the target DNA is amplified along with a known amount of competitor template that is distinguished from the target by a unique site in the template that does not exist in the target DNA. The target DNA amount in the sample is directly proportional to the amount of competitor needed to reduce its amplification. This type of method has been used to quantify S. subterranea from soil (Bell et al. 1999). Although quantifying the target DNA using the conventional PCR is an effective approach, it is more laborious to perform and does not have as high a throughput as quantitative real-time (qPCR). qPCR has revolutionized pathogen detection and quantification from various environmental samples (Schena et al. 2004). qPCR assays using TaqMan probes have been used to detect and quantify soilborne pathogens with higher specificity and precision and have opened an avenue to successfully develop assays that will detect multiple pathogens in a single PCR amplification assay (Okubara et al. 2005; Qu et al. 2011). A qPCR method was developed to detect and quantify $S$. subterranea in the soil, water, and plant tissue but was less consistent in quantifying the pathogen in soil due to inhibition of either the PCR method itself or the binding of DNA to soil particles (van de Graaf et al. 2003).

Enumerating the sporosori of $S$. subterranea is the only way to determine the inoculum density of the pathogen in soil and could be a useful management tool. For example, a potato producer would have the option not to plant to potato if a field had extremely high levels of $S$. subterranea sporosori. Alternatively, knowing the level of $S$. subterranea in soil could allow potato growers to plant certified scabfree seed tubers in soils devoid of the pathogen or at very low levels coupled with the use of potato cultivars that are resistant to the tuber or root phase of S. subterranea (Bittara et al. 2016; Falloon 2008; Merz and Falloon 2009). However, detecting and quantifying $S$. subterranea in the soil can be difficult because of various soil characteristics such as $\mathrm{pH}$, water content, soil textures, and possible PCR inhibition by organic matter (OM) (Tebbe and Vahjen 1993). One way to circumvent the PCR inhibition is to dilute the DNA extract but this approach may result in compromising sensitivity of the PCR reaction, especially if the pathogen inoculum level is low. Furthermore, S. subterranea sporosori are heterogeneously distributed in the soil as aggregates and are occasionally bound strongly to soil particles, making them difficult to extract (Robe et al. 2003).

S. subterranea survives in soil as sporosori and the extraction of DNA can be challenging given their multilayered cell walls and five-layered envelope (Lahert and Kavanagh 1985). Thus, an efficient grinding of the soil sample becomes an essential step prior to extraction of DNA (Frostegard et al. 1999). In recent years, the extraction of DNA from thick-walled microbes has greatly improved with the use of bead beaters or homogenizers, which efficiently disrupts the cells.

As a pivotal step in efficient soil management to prevent infection and disease development, numerous qPCR have been developed for detecting and quantifying soilborne pathogens affecting potato. (Bell et al. 1999; Bilodeau et al. 2012; Bittara et al. 2017; Braithwaite et al. 1994; Cullen et al. 2001, 2002; Dauch et al. 2006; DeSheilds et al. 2018). Additionally, an Australian-based company (SARDI Plant and Soil Health, Urrbrae, SA, Australia) has developed a DNAbased soil testing service called PREDICTA that reports the level of $S$. subterranea in the soil as picograms of DNA per gram of soil.

In qPCR, DNA quantification is achieved by the use of external DNA standards. Most commonly, these external DNA standards consist of serially diluted amounts of the target DNA sequence, whose concentrations are known and which are amplified in the same run as the unknown samples but in separate reactions. This approach has been employed in the quantification of several pathogens (Wilhelm and Pingoud 2003). The variations in the soil due to its physical characters and OM content can result in inconsistent DNA extraction and, hence, the quantification data. Introduction of an external control (EC) to the soil or to the soil DNA extract at a specific concentration can address the problem (Balendres et al. 2018; Daniell et al. 2012; Dauch et al. 2006; Thangavel et al. 2015). The main principle behind this method relies on the fact that, if EC is added to the soil samples or extracts at an identical amount, the calculated EC after the qPCR should be similar in all of the samples. Any deviation in the quantified EC is a reflection of variable PCR efficiency and the values are normalized. In some qPCR methods, a separate plasmid consisting of the target gene is used to create a standard curve to compare and quantify the pathogen (Bittara et al. 2017; DeShields et al. 2018).

The goal of the study reported here was to design a qPCR protocol for quantifying $S$. subterranea sporosori using sporosori-spiked soil to generate a standard curve as a reference for quantification with the addition of an EC applied directly to soil samples prior to DNA extraction to monitor the $\mathrm{qPCR}$ and to normalize data among soil samples.

\section{Materials and Methods}

Soil collection and characterization. Soil samples were collected initially from four separate counties in Minnesota to be used in the development of the protocol (Table 1). The soil samples were collected by removing the upper $5 \mathrm{~cm}$ of soil from a 20-cm-deep core. A minimum of 8 to 10 cores was collected from each field and placed in a soil sampling bag. Once the soils were collected, they were air dried at room temperature for 3 to 4 days, followed by the grinding of each soil individually to a fine powder using a "flail-type" soil pulverizer (Agvise). The pulverizer was dusted, sprayed, and wiped with alcohol between grinding the soil samples to prevent cross-contamination.

A subsample of each ground soil (approximately $10 \mathrm{~g}$ ) from the four locations collected in Minnesota was submitted to the Soil Science Department at North Dakota State University for analysis of physical properties, including the $\mathrm{pH}$, soil texture, and OM content.

Spiking soil with $S$. subterranea sporosori. Soils to be used for spiking were autoclaved twice at $121^{\circ} \mathrm{C}$ for $60 \mathrm{~min}$ to eliminate any naturally occurring $S$. subterranea sporosori. After sterilization, the soil was tested for $S$. subterranea by real-time PCR following DNA extraction using published $S$. subterranean-specific primers and probes to confirm the absence of sporosori (van de Graaf et al. 2003). Because $S$. subterranea is an obligate parasite and cannot be cultured in artificial media, the sporosori used to spike soil were harvested from the root galls of infected potato plants. The sporosori were obtained by consecutive sieving of air-dried S. subterranea-infected root tissue using 45- to 150-mm-mesh sieves. S. subterranea sporosori were counted using a hemocytometer and adjusted to 120,000 sporosori/ml with nuclease-free water. The $S$. subterranea sporosori suspensions consisted of $12,000,1,200,120,12$, and 1 sporosori/ml. The sporosori in each suspension were counted again using a hemocytometer to confirm the dilutions. The $S$. subterranea sporosori suspension was added to aliquots of autoclaved soil to have $120,000,12,000,1,200,120,12$, and 1 sporosori/g of soil. The soilsporosori mix was subsequently air dried in the dark at $22 \pm 2{ }^{\circ} \mathrm{C}$ for 7 days. The DNA extracted from spiked soil was used to create a standard curve for quantifying $S$. subterranea sporosori.

DNA extraction from sporosori and soils. DNA was extracted from the serially diluted sporosori in nuclease-free water suspensions using a FastDNA spin kit (MP Biomedicals) following the manufacturer's directions, with an additional step of homogenization using the FastPrep-24 desktop homogenizer (MP Biomedicals) at a setting of 6 for $40 \mathrm{~s}$. DNA from the spiked soils were extracted using the DNAeasy PowerSoil DNA isolation kit (Qiagen) following the protocol provided by the manufacturer. An additional step of homogenizing the soil using a FastPrep-24 desktop homogenizer at a setting of 6 for $40 \mathrm{~s}$ was also introduced in addition to vortexing the soil for $15 \mathrm{~min}$ on a horizontal vortex platform at a medium speed according to the instructions in the manufacturer's protocol. The DNA obtained from the extractions was quantified using a NanoDrop 2000c UV-Vis spectrophotometer (Thermo Scientific). 
EC. Enumeration of pathogens in soil samples requires efficient and reproducible methods for DNA extraction as well as qPCR. In order to avoid the inconsistency and inefficiency of DNA extraction from soil followed by qPCR, an EC, previously designed to amplify a 103-bp M13 phage fragment of the plasmid pUC19, was added to the soil samples prior to DNA extraction.

The vector pUC19 was used as a template for amplifying a 103-bp amplicon using the primers (M13-F and M13-R) and probe (M13-P) (Table 2). Although the primers for amplifying the 103-bp amplicon were predesigned and published (Dauch et al. 2006), the probe for detecting the EC in qPCR was designed in this study by using the sequence provided by the manufacturer (New England Biolabs) as template and Primer 3Plus software. A melt-curve analysis for the qPCR was generated using SsoAdvanced Universal SYBR Green Supermix (Bio-Rad) to rule out the possibility of primer-dimer formation and optimize the primer or probe concentration. The SYBR Green reaction mix consisted of $10 \mu 1$ of SsoAdvanced Universal SYBR Green Supermix along with different concentrations (ranging from 250 to $50 \mathrm{nM}$ ) of forward and reverse primers in a $20-\mu l$ reaction. The amplification protocol to obtain an optimum SYBR melt curve was an initial polymerase activation and DNA denaturation for $2 \mathrm{~min}$ at $98^{\circ} \mathrm{C}$, followed by 30 cycles of $2 \mathrm{~s}$ denaturation at $98^{\circ} \mathrm{C}$ and annealing at $58^{\circ} \mathrm{C}$. The melt-curve analysis was performed at a $0.5^{\circ} \mathrm{C}$ increment of $2 \mathrm{~s}$ per step. The SYBR Green assays were performed in a Bio-Rad CFX 96 Real-Time system (Bio-Rad).

EC was added directly to the soil samples before the DNA extraction, during the extraction procedure, and after the extraction of DNA. To test the EC detection threshold, EC was added at concentrations of $40 \mathrm{ng}, 4 \mathrm{ng}, 400 \mathrm{pg}, 40 \mathrm{pg}$, and $4 \mathrm{pg}$ per gram of soil. The final concentration of $S$. subterranea sporosori in different soil samples was calculated with the EC concentration in consideration to normalize any deviations.

Single and duplex qPCR. The qPCR was performed in a Bio-Rad CFX 96 Real-Time system. A $20-\mu 1$ reaction mix comprising 250 and $125 \mathrm{nM}$ pathogen-specific primers and probe in $1 \times$ SsoAdvanced Universal Probes Supermix (Bio-Rad) was subjected to 40 cycles of amplification at $94^{\circ} \mathrm{C}$ for $15 \mathrm{~s}$ and $58^{\circ} \mathrm{C}$ for $45 \mathrm{~s}$. An initial step of denaturation at $95^{\circ} \mathrm{C}$ for 2 min was added before the actual amplification cycles. The $S$. subterranea $(\mathrm{SsTqF} 1 / \mathrm{SsTqR} 1)$-specific primers were added at a concentration of $250 \mathrm{nM}$ each and $S$. subterranea (SsTqP1)-specific probes were added at a concentration of $125 \mathrm{nM}$ each in $1 \times$ SsoAdvanced Universal Probes Supermix (Bio-Rad). DNA $(2 \mu \mathrm{l})$ was added to $18 \mu \mathrm{l}$ of reaction mix.

In the duplex qPCR, primers (M13-F and M13-R) and probe (M13-P) specific to the M13 sequence were added in a concentration of 125 and $32 \mathrm{nM}$, respectively, in addition to primers and probes added previously in the single qPCR. The amplification cycling conditions were identical in single and duplex qPCR.

A negative control was included in each qPCR assays, consisting of autoclaved soil devoid of $S$. subterranea as confirmed with qPCR. Additionally, a no-template reaction consisting of nuclease-free water was included in each qPCR run, too.

Validation and comparison of qPCR sporosori detection in water suspension and spiked soil. DNA extracted from spiked sandy loam soil with known $S$. subterranea sporosori concentrations in nuclease-free water was generated to construct the external standards. These external standards were subjected to qPCR in a BioRad CFX96 real-time system to determine the detection limits and efficiencies. The detection efficiencies and coefficient of determination ( $R^{2}$ values) were calculated from the graphs and slopes generated with Bio-Rad CFX software (version 3.1; Bio-Rad). A standard curve was generated using DNA extracted from just the sporosori suspensions in nuclease-free water to compare with the standard curve obtained from the sporosori-spiked soils. For comparing the qPCR in spiked soil and water, the soil with sandy texture from Otter Tail County, MN was arbitrarily chosen.

Quantification of $\boldsymbol{S}$. subterranea in commercial fields. We received 443 soil samples across the United States from commercial fields located in Colorado, Idaho, Maine, Michigan, Nebraska, New York, and Washington for detecting and quantifying S. subterranea during the 2017 and 2018 calendar years. The potato growers and researchers were instructed to collect samples following a protocol similar to that described earlier. Briefly, soil samples were collected by removing the upper $5 \mathrm{~cm}$ of soil from a 20-cm-deep core. Compound samples consisting of at least 8 to 10 cores were collected from the same field and placed in a soil sampling bag. The growers were asked to collect soil from the four quadrants of a field, resulting in multiple subsamples from the same field sample. The subsamples provided a representation of the $S$. subterranea sporosori amount present in that particular field sample. Once the soils were collected, they were air dried at room temperature for 3 to 4 days, followed by grinding each soil individually, as described earlier, using a flail-type soil pulverizer.

Table 1. Validation of Spongospora subterranea sporosori in quantitative real-time PCR (qPCR) in four different soil types collected from four separate counties in Minnesota ${ }^{a}$

\begin{tabular}{|c|c|c|c|c|c|c|c|c|}
\hline \multirow[b]{2}{*}{ Field soil } & \multirow[b]{2}{*}{ County } & \multirow[b]{2}{*}{ OM } & \multirow[b]{2}{*}{ pH } & \multirow[b]{2}{*}{ Soil texture } & \multicolumn{2}{|c|}{ Single qPCR ${ }^{b}$} & \multicolumn{2}{|c|}{ Duplex qPCR ${ }^{c}$} \\
\hline & & & & & Efficiency (\%) & $R^{2}$ & Efficiency (\%) & $\overline{R^{2}}$ \\
\hline 1 & Sherburne & 2.1 & 5.5 & Sandy loam & 94 & 0.99 & 95 & $\overline{0.99}$ \\
\hline 2 & Otter Tail & 1.1 & 5.8 & Sand & 92 & 0.99 & 99 & 0.98 \\
\hline 3 & Becker & 1.2 & 6.3 & Loamy sand & 98 & 0.99 & 99 & 0.99 \\
\hline 4 & Hubbard & 4.8 & 8.1 & Silt clay loam & 97 & 0.98 & 94 & 0.99 \\
\hline
\end{tabular}

a Soil samples varied in organic matter (OM) content, $\mathrm{pH}$, and soil texture. The efficiency and $R^{2}$ values of single qPCR and duplex qPCR were compared among these soil types.

${ }^{\mathrm{b}} \mathrm{qPCR}$ targeting S. subterranea sporosori only.

c qPCR targeting $S$. subterranea sporosori and external control (pUC19).

Table 2. Primers and probes used in this study

\begin{tabular}{llcccc}
\hline Primer or probe & \multicolumn{1}{c}{ Sequence } & Amp (bp) $)^{\mathbf{a}}$ & Gene $^{\mathbf{b}}$ & Fluor $^{\mathbf{c}}$ & Reference $^{\text {van de Graaf et al. 2003 }}$ \\
\hline SsTQF1 & CCGGCAGACCCAAAACC & 61 & ITS & Fam & $\ldots$ \\
SsTQR1 & CGGGCGTCACCCTTCA & $\ldots$ & $\ldots$ & $\ldots$ & $\ldots$ \\
SsTQP1 & CAGACAATCGCACCCAGGTTCTCATG & $\ldots$ & $\ldots$ & $\ldots$ & $\ldots$ \\
M13-F & GTAAAACGACGGCCAG & 103 & M13 & $\ldots$ & Dauch et al. 2006 \\
M13-R & CAGGAAACAGCTATGAC & $\ldots$ & $\ldots$ & $\ldots$ & $\ldots$ \\
M13P & GTACCCGGGGATCCTCTAGA & $\ldots$ & $\ldots$ & Texas Red & This study \\
\hline
\end{tabular}

\footnotetext{
a Amplicon size.

b Target gene.

c Fluorophore.
} 
The pulverizer was dusted, sprayed, and wiped with alcohol between grinding the soil samples to prevent cross-contamination.

A standard curve was generated by qPCR with 10 -fold dilutions of known concentrations of $S$. subterranea sporosori in the spiked soil. The cycle threshold $(\mathrm{Ct})$ values obtained from the standard curve were used to calculate the number of $S$. subterranea sporosori with Bio-Rad CFX software (version 3.1; Bio-Rad).

For normalizing the data, pUC19 vector (EC) was added in equal amounts at a concentration of $40 \mathrm{pg} / \mathrm{g}$ of soil to the soil samples with unknown pathogen levels. The $\mathrm{Ct}$ values of the $\mathrm{EC}$ in each reaction were taken into consideration for normalizing the data using the formula Normalized amount $=(S$. subterranea sporosori of each sample/EC of each sample) $\times$ Average of total EC.

Based on initial results from qPCR, we could differentiate soil levels of $S$. subterranea which led us to arbitrarily establish categories as low $\left(<10^{2}\right.$ sporosori/g of soil), with $\mathrm{Ct}$ values ranging from 32 to 35 ; moderate (from $10^{2}$ to $10^{4}$ sporosori/g of soil), with $\mathrm{Ct}$ values ranging from about 22 to 31 ; and high ( $>10^{4}$ sporosori/g of soil), with $\mathrm{Ct}$ values of 21 and lower.

Experiments were conducted to compare the $S$. subterranea sporosori count in normalized and nonnormalized soil samples from commercial fields. Soil samples from four different commercial fields located in Washington, Maine, Idaho, and New York were randomly chosen for these experiments. The soil samples were divided into two sets. In one set of the soil sample, EC was added to the sample at a concentration of $40 \mathrm{pg} / \mathrm{g}$ of soil, and a duplex qPCR was performed targeting the $S$. subterranea sporosori and M13 sequence in the EC, as described earlier. The $S$. subterranea sporosori per gram of soil was calculated based on the $\mathrm{Ct}$ values obtained from the standard curve and final $S$. subterranea sporosori per gram was reported after normalizing the data with $\mathrm{Ct}$ values of $\mathrm{EC}$, as described previously. EC was not added to the second set of soil samples representing the nonnormalized soil samples. A single qPCR targeting the $S$. subterranea sporosori was performed, after which the number of S. subterranea sporosori per gram of soil was calculated based on the $\mathrm{Ct}$ values obtained from the standard curve. In the second set of soil samples, the $\mathrm{Ct}$ values were not normalized with EC. The experiments were conducted twice and an average sporosori per gram in both normalized and nonnormalized soil samples were calculated and compared.

S. subterranea sporosori detection in potting mix. The protocol of creating the standard curve by spiking the autoclaved soil, adding the EC, and quantifying the $S$. subterranea sporosori after normalization was shared with a research laboratory at Colorado State University. The protocol was implemented to enumerate the $S$. subterranea sporosori in the soil samples containing high OM such as an artificial greenhouse potting mix consisting principally of sphagnum peat moss.

The autoclaved soil was spiked with $S$. subterranea sporosori similarly as described earlier to create a set of six external standards. The EC was added at a concentration of $40 \mathrm{ng} / \mathrm{g}$ of the potting mix prior to DNA extraction.

Twenty-three potting mix samples were submitted to the Colorado State University Plant Diagnostic Clinic. Each sample was mixed and dried at room temperature. After drying, samples were ground using a blade coffee grinder (Model BCG111OB; KitchenAid). DNA was extracted from the ground potting mix in duplicate using the DNeasy PowerSoil DNA isolation kit (Qiagen), following the manufacturer's instructions, with some modification. Initial homogenization was performed using a FastPrep FP120 Cell Disrupter (Thermo Savant) at a setting of 6 for $40 \mathrm{~s}$, followed by vortexing for $15 \mathrm{~min}$ on a horizontal vortex platform. DNA was eluted in $50 \mu$ l of kit elution buffer. The qPCR amplification of $S$. subterranea DNA was performed on a QuantStudio 3 Real-Time PCR System (Thermo Fisher Scientific), following the protocol as previously described for field soil samples.

Statistical analysis. Pearson correlations (SAS PROC CORR) were performed to study the relationship between the amount of sporosori in nuclease-free water, DNA concentration of sporosori in water, and their associated $\mathrm{Ct}$ values. The correlation procedure was repeated for the amount of sporosori in soil, DNA concentration of sporosori in the soil, and their associated $\mathrm{Ct}$ values. Furthermore, a correlation coefficient was used to study the association between sporosori in nuclease-free water and sporosori in the soil.

The soils spiked with serially diluted $S$. subterranea sporosori were used to generate a qPCR standard curve using duplicate samples from each spiked soil aliquot. The spiking experiment was repeated 30 times for each of the four soil types to generate sufficient data for the statistical analysis. Reproducibility of qPCR data in a single type of soil was analyzed by first calculating the standard deviation of the data and then dividing it by the square root of the number of observations to obtain the standard deviation of the mean. The detection efficiency and $R^{2}$ values for qPCR were calculated using the BioRad CFX software, version 3.1, as stated above. The $R^{2}$ values were compared among different soil types by calculating the $P$ value using analysis of variance (PROC ANOVA) in statistical analysis software (SAS 9.4 version).

\section{Results}

Soil types and DNA extraction. The soil samples collected from four different potato-producing counties in Minnesota were evaluated for their physical properties, including $\mathrm{pH}$, texture, and $\mathrm{OM}$ content, and were found to vary substantially (Table 1). The OM ranged from 1.1 to 4.8 whereas the $\mathrm{pH}$ ranged from 5.5 to 8.1 . Soils textures ranged from sand to sandy loam, loamy sand, and silt clay loam. This range of soil types provided us with an opportunity to study and compare the efficiency of DNA extraction and pathogen detection efficiencies among different soil types.

Coextraction of EC. The 103-bp fragment of M13 using the pUC19 vector as a template was consistently amplified using the primers (M13-F and M13-R) and probe (M13-P) along with S. subterranea sporosori when the duplex qPCR was performed.

The EC was introduced to the soil samples at various points of DNA extraction method at a concentration of $40 \mathrm{pg} / \mathrm{g}$ of soil. It was directly added to the soil before the DNA extraction procedure, during the DNA extraction process after pretreatment steps, and to the soil DNA extract (Table 3). It was noted that EC was detected in all of the samples, albeit with different $\mathrm{Ct}$ values, suggesting different concentrations. There was some loss of EC when added directly to the soil as compared with when the EC was added during and after the extraction (Table 3). The final sporosori per gram of soil did not change appreciably regardless of when the EC was added at different points before, during, and after DNA extraction (Table 3). These results suggest that the EC can be added directly to the soil prior to DNA extraction and, hence, will aid in monitoring the efficiency of both DNA extraction and the duplex qPCR at the same time.

The amount of S. subterranea sporosori per gram of soil was normalized and calculated using the EC values, as described (Table 4). Numbers of sporosori per gram reported after normalizing were different than the value before normalizing. The $\mathrm{Ct}$ values for $\mathrm{EC}$ were found to be consistent.

Three replicate experiments were conducted to study the threshold amount of the EC that can be used to spike the soil for normalizing and quantification. It was found that an EC concentration as low as $40 \mathrm{pg} / \mathrm{g}$ of soil provided a Ct value of around 28 in the duplex qPCR (Table 4). The EC was not detected consistently in soil samples spiked with $4 \mathrm{pg} / \mathrm{g}$ of soil. It was decided to use an EC concentration $40 \mathrm{pg} / \mathrm{g}$ of soil for spiking the soil in further experiments.

Validation and efficiency detection of qPCR. The DNA concentration extracted from serially diluted $S$. subterranea sporosoriwater suspension was found to be directly proportional to the amount of sporosori in the soil (Table 5). The serially diluted S. subterranea sporosori-water suspension was then spiked in the soil. Pearson correlations analysis demonstrated that the amount of $S$. subterranea sporosori in water and soil was significant $(P<0.05)$ and strongly correlated with the DNA concentration in both water and soil, with correlation coefficients $(r)$ of 0.92 and 0.82 , respectively. The lower correlation between $S$. subterranea sporosori numbers in soil and DNA concentration is most likely due to the extraction of 
Table 3. External control (EC) added to soil at various steps of DNA extraction procedure

\begin{tabular}{|c|c|c|c|c|c|c|c|}
\hline Number & Sample & Target & Sporosori/g soil ${ }^{a}$ & $\mathbf{P S}^{\mathbf{b}}$ & Sample ${ }^{c}$ & Target & $E C(C t)^{d}$ \\
\hline 1 & Soil A & Sporosori & $4,551.70$ & M & Direct & M13 & 28.3 \\
\hline 2 & Soil B & Sporosori & $8,756.98$ & M & Direct & M13 & 28.7 \\
\hline 3 & Soil C & Sporosori & 61.24 & $\mathrm{~L}$ & Direct & M13 & 28.3 \\
\hline 4 & Soil D & Sporosori & 33.48 & $\mathrm{~L}$ & Direct & M13 & 29.3 \\
\hline 5 & Soil E & Sporosori & $3,858.77$ & M & Direct & M13 & 28.8 \\
\hline 6 & Soil F & Sporosori & $\ldots$ & $\mathrm{N}$ & Direct & M13 & 28.5 \\
\hline 7 & Soil A & Sporosori & $4,550.01$ & M & During & M13 & 26.3 \\
\hline 8 & Soil B & Sporosori & $8,775.45$ & M & During & M13 & 26.1 \\
\hline 9 & Soil C & Sporosori & 63.21 & $\mathrm{~L}$ & During & M13 & 25.3 \\
\hline 10 & Soil D & Sporosori & 32.76 & $\mathrm{~L}$ & During & M13 & 26.0 \\
\hline 11 & Soil E & Sporosori & $3,824.93$ & M & During & M13 & 25.0 \\
\hline 12 & Soil F & Sporosori & $\ldots$ & $\mathrm{N}$ & During & M13 & 26.0 \\
\hline 13 & Soil A & Sporosori & $4,555.04$ & M & After & M13 & 24.0 \\
\hline 14 & Soil B & Sporosori & $8,745.12$ & M & After & M13 & 25.0 \\
\hline 15 & Soil C & Sporosori & 63.80 & $\mathrm{~L}$ & After & M13 & 24.2 \\
\hline 16 & Soil D & Sporosori & 33.31 & $\mathrm{~L}$ & After & M13 & 24.2 \\
\hline 17 & Soil E & Sporosori & $3,812.82$ & M & After & M13 & 25.7 \\
\hline 18 & Soil F & Sporosori & $\ldots$ & $\mathrm{N}$ & After & M13 & 24.4 \\
\hline
\end{tabular}

${ }^{a}$ Final Spongospora subterranea sporosori levels were calculated using the formula Normalized amount $=(S$. subterranea sporosori of each sample/EC of each sample) $\times$ Average of total EC.

${ }^{\text {b }}$ Based on initial results, the $S$. subterranea categories were arbitrarily grouped as low (L; $<10^{2}$ sporosori/g of soil), moderate (M; $10^{2}$ to $10^{4}$ sporosori/g of soil), and high $\left(\mathrm{H} ;>10^{4}\right.$ sporosori/g of soil). $\mathrm{N}=$ negative.

${ }^{c}$ Direct $=$ EC added directly to soil, During $=$ EC added during DNA extraction, and After $=$ EC added after DNA extraction

${ }^{\mathrm{d}} \mathrm{EC}$ (pUC19) was added at a concentration of $40 \mathrm{pg} / \mathrm{g}$ of soil. $\mathrm{Ct}=$ cycle threshold.

Table 4. Quantification of Spongospora subterranea sporosori per gram of soil after normalizing the values using an external control (EC)

\begin{tabular}{|c|c|c|c|c|c|c|c|c|}
\hline \multirow[b]{2}{*}{ Number } & \multirow[b]{2}{*}{ Sample } & \multirow[b]{2}{*}{ Target } & \multicolumn{3}{|c|}{ Sporosori/g of soil } & \multirow[b]{2}{*}{$\mathbf{P S}^{\mathbf{b}}$} & \multirow[b]{2}{*}{ Target } & \multirow[b]{2}{*}{$\mathbf{E C}(\mathbf{C t})^{\mathbf{c}}$} \\
\hline & & & Non-normalized & Normalized $^{\mathbf{a}}$ & Final & & & \\
\hline 1 & Spiked soil & Sporosori & 120,000 & $121,147.6$ & $120,434.3$ & $\mathrm{H}$ & M13 & 28.92 \\
\hline 2 & Spiked soil & Sporosori & 120,000 & $119,720.9$ & $\ldots$ & $\ldots$ & M13 & 28.58 \\
\hline 3 & Spiked soil & Sporosori & 12,000 & $11,937.6$ & $12,026.7$ & $\mathrm{H}$ & M13 & 28.50 \\
\hline 4 & Spiked soil & Sporosori & 12,000 & $12,115.7$ & $\ldots$ & $\ldots$ & M13 & 28.92 \\
\hline 5 & Spiked soil & Sporosori & 1,200 & $1,205.0$ & $1,203.5$ & $\mathrm{M}$ & M13 & 28.76 \\
\hline 6 & Spiked soil & Sporosori & 1,200 & $1,202.0$ & $\ldots$ & $\ldots$ & M13 & 28.69 \\
\hline 7 & Spiked soil & Sporosori & 120 & 119.4 & 120.2 & M & M13 & 28.49 \\
\hline 8 & Spiked soil & Sporosori & 120 & 121.0 & $\ldots$ & $\ldots$ & M13 & 28.87 \\
\hline 9 & Spiked soil & Sporosori & 12 & 12.0 & 12.0 & $\mathrm{~L}$ & M13 & 28.60 \\
\hline 10 & Spiked soil & Sporosori & 12 & 12.0 & $\ldots$ & $\ldots$ & M13 & 28.58 \\
\hline 11 & Spiked soil & Sporosori & 1 & 1.0 & 1.0 & $\mathrm{~L}$ & M13 & 28.46 \\
\hline 12 & Spiked soil & Sporosori & 1 & 1.0 & $\ldots$ & $\ldots$ & M13 & 28.24 \\
\hline 13 & Sample 1 Rep 1 & Sporosori & $404,844.2$ & $406,188.6$ & $404,941.8$ & $\mathrm{H}$ & M13 & 28.66 \\
\hline 14 & Sample 1 Rep 2 & Sporosori & $404,844.2$ & $403,695.0$ & $\ldots$ & $\ldots$ & M13 & 28.56 \\
\hline 15 & Sample 2 Rep 1 & Sporosori & 60.6 & 61.2 & 57.0 & $\mathrm{~L}$ & M13 & 28.83 \\
\hline 16 & Sample 2 Rep 2 & Sporosori & 52.6 & 52.8 & $\ldots$ & $\ldots$ & M13 & 28.75 \\
\hline 17 & Sample 3 Rep 1 & Sporosori & $317,893.7$ & $319,719.4$ & $321,711.1$ & $\mathrm{H}$ & M13 & 28.73 \\
\hline 18 & Sample 3 Rep 2 & Sporosori & $323,428.0$ & $323,711.8$ & $\ldots$ & $\ldots$ & M13 & 28.67 \\
\hline 19 & Sample 4 Rep 1 & Sporosori & 171.6 & 171.1 & 164.2 & M & M13 & 28.48 \\
\hline 20 & Sample 4 Rep 2 & Sporosori & 157.8 & 157.4 & $\ldots$ & $\ldots$ & M13 & 28.57 \\
\hline
\end{tabular}

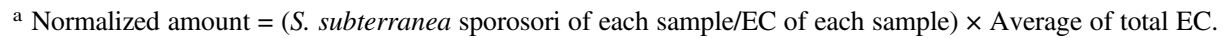

b Based on initial results, the $S$. subterranea categories were arbitrarily grouped as low (L; $<10^{2}$ sporosori/g of soil), moderate (M; $10^{2}$ to $10^{4}$ sporosori/g of soil), and high $\left(\mathrm{H} ;>10^{4}\right.$ sporosori/g of soil).

${ }^{\mathrm{c}}$ External control (pUC19) was added at a concentration of $40 \mathrm{pg} / \mathrm{g}$ of soil prior to DNA extraction. $\mathrm{Ct}=$ cycle threshold. Total average EC $=28.64$.

Table 5. Comparison of DNA concentration and cycle threshold $(\mathrm{Ct})$ values between Spongospora subterranea sporosori in water and soil

\begin{tabular}{|c|c|c|c|c|c|}
\hline \multicolumn{3}{|c|}{ Sporosori in water } & \multicolumn{3}{|c|}{ Sporosori in soil } \\
\hline Sporosori/ml & DNA $(n g / \mu l)^{a}$ & Ct values & Sporosori/g of soil & DNA $(n g / \mu l)^{b}$ & Ct values \\
\hline 120,000 & 38.1 & 18.4 & 120,000 & 57.6 & 18.7 \\
\hline 12,000 & 19.7 & 22.4 & 12,000 & 55.8 & 22.1 \\
\hline 1,200 & 5.9 & 25.0 & 1,200 & 53.2 & 25.4 \\
\hline 120 & 7.5 & 28.3 & 120 & 52.7 & 28.3 \\
\hline 12 & 3.5 & 32.3 & 12 & 52.7 & 32.1 \\
\hline 1 & 1.8 & 35.9 & 1 & 52.4 & 35.2 \\
\hline
\end{tabular}

${ }^{a}$ DNA concentration reflects total DNA extracted from S. subterranea sporosori dilutions in water before spiking, including target (S. subterranea sporosori) and external control (EC).

b DNA concentration reflects total DNA extracted from soil after spiking with S. subterranea sporosori dilutions, including target (S. subterranea sporosori), EC, and naturally occurring nontarget DNA. 
DNA from naturally occurring nontarget entities in a complex sample such as soil. The detection efficiencies of $S$. subterranea sporosori in both water and soil were found to be $95 \%$ and $R^{2}$ values of 0.99 , respectively.

The increase in S. subterranea sporosori numbers and a concomitant increase in target DNA concentration was expected to result in

\section{A}

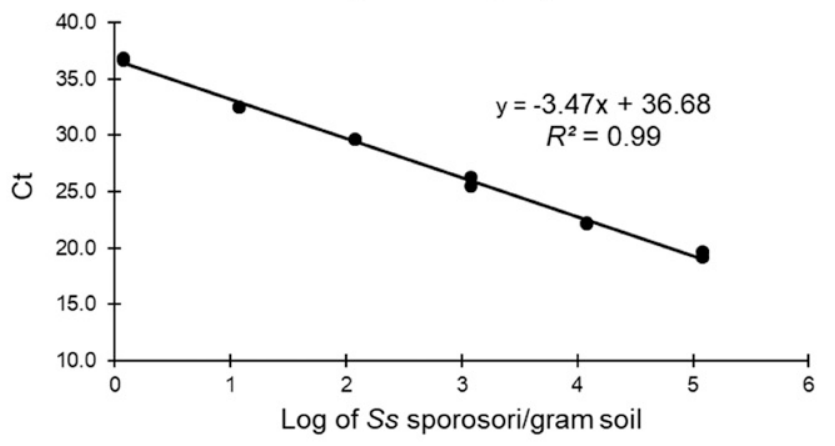

C

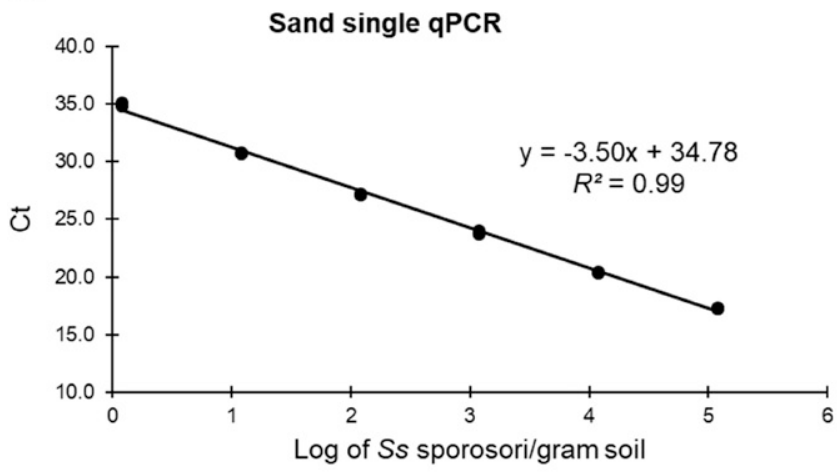

E

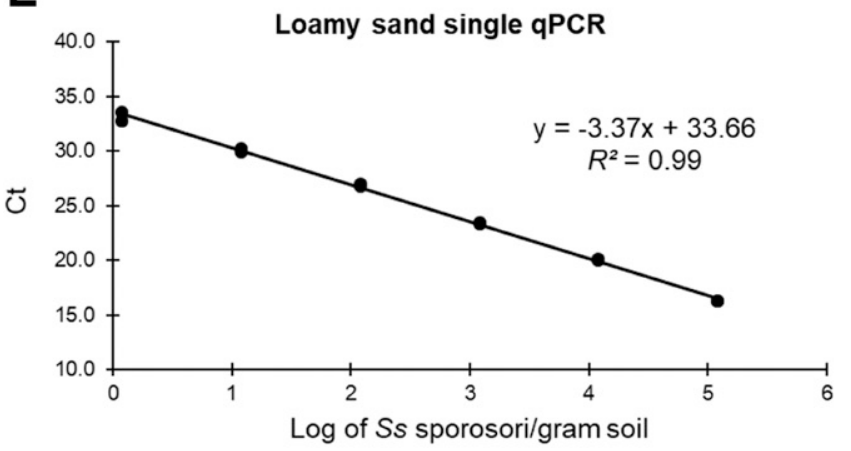

G

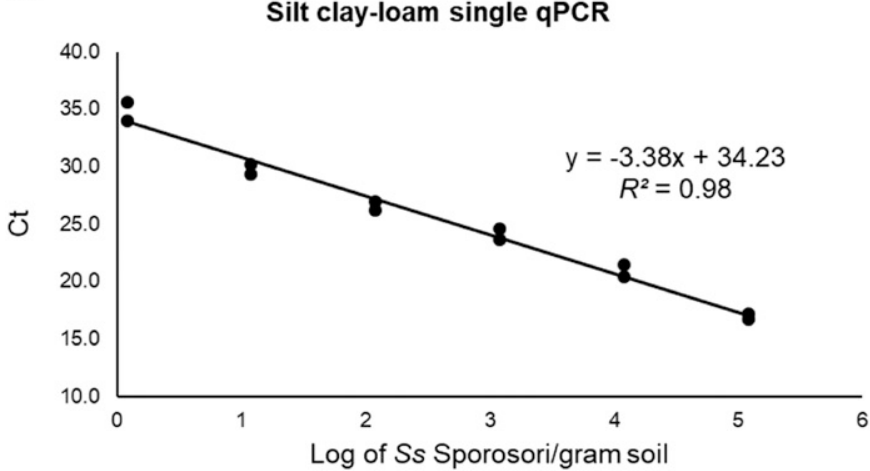

lower $\mathrm{Ct}$ values. This was confirmed by a significant $(P<0.05)$ negative correlation between $S$. subterranea sporosori numbers and the ensuing $\mathrm{Ct}$ values from soil $(r=-0.70)$ and water $(r=-0.72)$ assays, respectively. Furthermore, the relationship between $\mathrm{Ct}$ values of $S$. subterranea sporosori numbers in water and soil were significantly $(P<0.0001)$ and strongly $(r=0.99)$ correlated. These results led

B

Sandy loam duplex qPCR

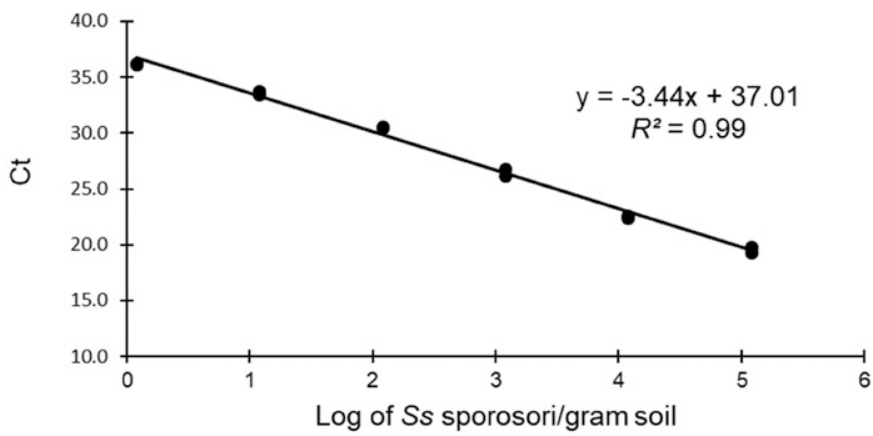

D
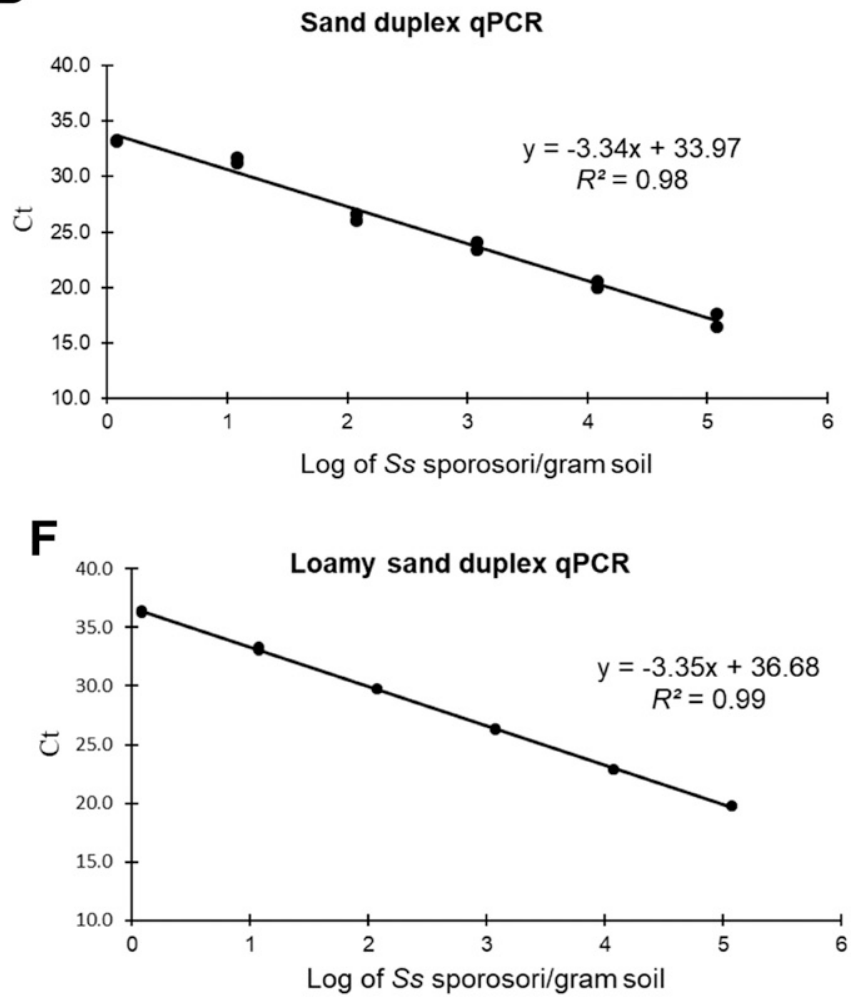

H

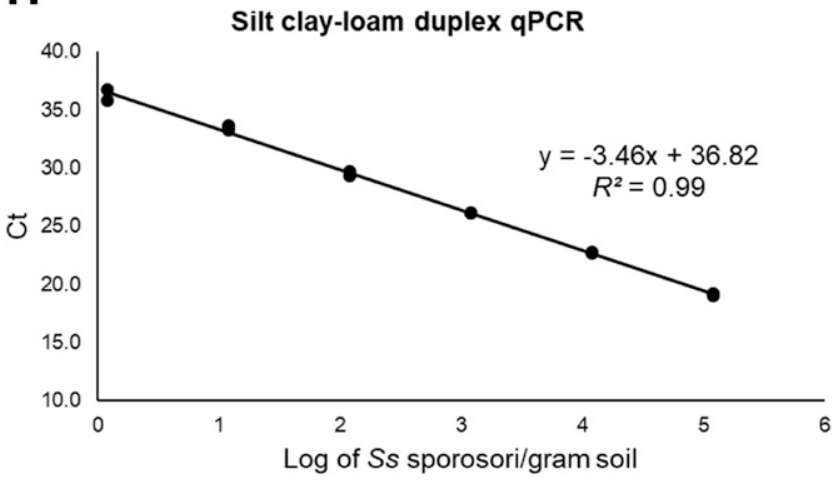

Fig. 1. Validation of quantitative real-time (qPCR) for quantifying Spongospora subterranea (Ss) sporosori per gram of soil in either a single (A, C, E, and G) or a duplex (B, D, F, and $\mathrm{H}) \mathrm{qPCR}$ along with external control. $\mathrm{Ct}=$ cycle threshold. 
us to extract DNA from soil spiked with serially diluted S. subterranea sporosori to successfully generate a standard curve to quantify the $S$. subterranea sporosori for diagnostic evaluations.

Sporosori in a sandy loam soil type from location $1(\mathrm{OM}=2.1, \mathrm{pH}$ 5.5) were detected with an efficiency of 94 and $95 \%$ in a single and duplex qPCR, respectively, with an $R^{2}$ value of the standard curve at 0.99 for both assays (Fig. 1A and B). In the soil with a sandy texture from location $2(\mathrm{OM}=1.1, \mathrm{pH} 5.8)$, the sporosori were detected with 92 and $99 \%$ efficiency and with $R^{2}$ values of 0.99 and 0.98 in single and duplex assays, respectively (Fig. 1C and D). Detection efficiency of sporosori in a loamy sand soil from location $3(\mathrm{OM}=1.2, \mathrm{pH} 6.3)$ ranged between 98 and $99 \%$ in both single and duplex qPCR, with similar $R^{2}$ values of 0.99 (Fig. $1 \mathrm{E}$ and $\mathrm{F}$ ). The detection level of sporosori in a silt clay loam soil ( $\mathrm{OM}=4.8, \mathrm{pH} 8.1)$ from location 4 had an efficiency of $97 \%$ in single qPCR but slightly lower efficiency of $94 \%$ in the duplex qPCR, with $R^{2}$ values of 0.98 and 0.99 , respectively (Fig. $1 \mathrm{G}$ and $\mathrm{H}$ ). The standard deviation of the mean calculated on the basis of assay efficiency and $R^{2}$ value using qPCR assay data collected from $S$. subterranea sporosori-spiked soil from experiments of soil from the same location performed 30 times was determined to be zero. This indicates that there was no variation among the results obtained from $\mathrm{qPCR}$ on a similar type of soil.

ANOVA results demonstrated that there were no significant differences among the four different soil types for both the qPCR efficiency $(P$ value $=0.83)$ and $R^{2}$ values $(P$ value $=0.55)$. The results from statistical analysis suggest that the qPCR protocol can be used in these four different soils without any significant difference in the final quantification results.

Quantification of $S$. subterranea from commercial fields. Soil samples from 443 potato fields from several U.S. locations were used to quantify S. subterranea sporosori (Table 6) during 2017 and 2018. Of the 120 soil samples from Colorado, $68 \%$ of soil tested positive for $S$. subterranea, with $42 \%$ consisting of moderate levels of $S$. subterranea sporosori $\left(10^{2}\right.$ to $10^{4}$ sporosori/g of soil) and $58 \%$ with low levels of sporosori $\left(<10^{2}\right.$ sporosori/g of soil). In contrast, in 32 soil samples from Nebraska, $3 \%$ were positive for $S$. subterranea, all consisting of low levels of $S$. subterranea sporosori. In total, 22 soil samples were tested from Michigan and $41 \%$ tested positive, with $78 \%$ of those showing low levels of S. subterranea sporosori and $22 \%$ with moderate $S$. subterranea sporosori levels. Approximately $91 \%$ of soil samples assayed from Maine were positive for S. subterranea, with $46 \%$ with low levels of $S$. subterranea, $52 \%$ moderate levels, and $2 \%$ possessing a high level of $S$. subterranea $\left(>10^{4}\right.$ sporosori/g of soil). In all, 126 soil samples from Washington were assayed for S. subterranea, of which $80 \%$ tested positive for the pathogen. Among the $S$. subterranea-positive soil samples, 50\% were found to have a low level, $46 \%$ exhibited a moderate level, and $4 \%$ had a high level of $S$. subterranea sporosori. Only four soil samples from Idaho were assayed for $S$. subterranea, with two testing positive, and both positive samples were found to have moderate levels of S. subterranea sporosori. In total, 30 soil samples were tested from New York; $67 \%$ tested positive, with $35 \%$ showing low levels of S. subterranea sporosori and $65 \%$ with moderate S. subterranea sporosori levels.

The estimated S. subterranea sporosori per gram of soil were compared between soil samples normalized with the addition of EC and those soil samples that were not normalized (Table 7). There was a difference in the sporosori numbers in all samples from the commercial fields located from four different states in the United States. The difference in S. subterranea sporosori levels varied from 74.3 to 1,618.6 sporosori/g of soil. There were substantial differences in sporosori per gram of soil between the normalized and nonnormalized soil samples from Washington and Maine. In the soil sample from Washington, the nonnormalized soil indicated an average count of $31,490.2$ sporosori/g of soil. When the same soil sample was normalized by adding EC and the number of sporosori was calculated after considering the EC Ct values, the average count was 33,108.8 sporosori/g of soil. There was a difference in S. subterranea sporosori by a value of 1,618.6 sporosori/g of soil. Similarly, the differences in the sporosori count were by a value of 1,248.9, 74.3, and
76 sporosori/g of soil in samples from Washington, Idaho, and New York, respectively.

Although a number of fields did not have any $S$. subterranea sporosori detected, the EC was amplified efficiently, suggesting that there was no inhibition during qPCR. The soil samples from these locations were verified to have lower OM, with an average value of 2.5, but a wide range of $\mathrm{pH}$, ranging from 4.8 to 8.4.

Detection of $S$. subterranea in potting mix. Apart from the grinding method of the potting mix, due to nonavailability of a pulverizer at Colorado State University, the qPCR procedure was performed exactly according to the protocol developed at North Dakota State University. The efficiency of qPCR for detecting the $S$. subterranea sporosori in the duplex PCR was reported to be between 94 and 99\% (data not shown). The qPCR efficiency was similar between the two research laboratories, even when the initial steps of grinding the soils differed. The $\mathrm{Ct}$ values of $\mathrm{EC}$ when used at a concentration of $40 \mathrm{pg} / \mathrm{g}$ of soil was consistent.

S. subterranea sporosori were quantified in 23 potting mix samples obtained from three different sources. These potting mixes consisted primarily of sphagnum peat moss, with an OM content ranging from 64 to $71 \%$. S. subterranea sporosori were detected in one sample from source A, three samples from source B, and one sample from source $\mathrm{C}$ (Table 8). Means of 4.90 sporosori/g of mix from source A, 1.26 sporosori/g of mix from source $\mathrm{B}$, and 5.72 sporosori/g of mix from source $\mathrm{C}$ were detected.

\section{Discussion}

Currently, there are no cost-effective chemical means to control powdery scab. The fungicide fluazinam, used as an in-furrow at planting application, has been demonstrated to suppress the disease on tubers (De Boer 2000; Falloon et al. 1996) (N. C. Gudmestad, unpublished) but it is questionable whether the level of disease reduction is worth the cost of application. Chloropicrin soil fumigation has been demonstrated to significantly reduce $S$. subterranea levels in the field; however, disease levels on roots and tubers can significantly increase despite lower pathogen inoculum levels (Bittara et al. 2017). Although potato cultivars vary in their susceptibility to the tuber scab and the root infection phases of $S$. subterranea, there are few cultivars with resistance to both phases of the disease (Bittara et al. 2016; Brierley et al. 2013; Falloon et al. 2003). Efficient detection and quantification of plant pathogens in the soil can be an effective first step in the control and management of soilborne diseases. Pathogen inoculum levels in soil are an important component for a number of soilborne diseases affecting potato and are important information for effective disease control (Gudmestad et al. 2007). For example, the economic threshold for $V$. dahliae in soil is approximately 8 to $10 \mathrm{microsclerotia/g}$ of soil for potato cultivars such as Russet Burbank (Nicot and Rouse 1987). Levels at or above this level of microsclerotia trigger management strategies such as the application of a soil fumigant. Although soil fumigation is not an effective means of controlling powdery scab (Bittara et al. 2017), a sensitive and rapid method to detect and quantify $S$. subterranea in soil may assist in the development of powdery scab management strategies that integrate soil levels and cultivar susceptibility that can reduce the economic impact of this disease (Brierley et al. 2009). Increasing levels of $S$. subterranea sporosori in soil have been demonstrated to increase disease incidence and severity (Brierley et al. 2013). However, results are not always so clear. A competitive PCR assay was used to test 29 potato fields in Japan (Nakayama et al. 2007). The highest $S$. subterranea level detected was 105 sporosori/g of soil and no evidence of a significant relationship between $S$. subterranea level in the soil and tuber disease severity was observed, which is in contrast to another published study (Brierley et al. 2013). However, there was a significant positive relationship between the severity of disease on roots and the tuber scab severity, suggesting that the number of successful secondary cycles of zoospores produced if conditions are favorable is an important factor. We believe that controlled studies (rather than using S. subterranea levels in fields that differ in many characteristics, including the environment) will be a more effective means to develop risk assessment models for powdery 
scab management. There may also be instances where the detection of $S$. subterranea in soil may allow potato growers to avoid those fields with moderate to high inoculum levels, thus evading the disease. Additionally, the detection of the pathogen in the potting mix at the greenhouse level may contribute to improved detection and elimination of the pathogen in disease-free potato seed programs. Also, monitoring the pathogen in those facilities avoids the spread of $S$. subterranea from the greenhouse to seed potato fields.

qPCR-based assays have been previously developed for the quantification of S. subterranea from soil (Brierley et al. 2009; van de Graaf et al. 2003). In the study conducted by van de Graaf et al. (2003) to quantify the $S$. subterranea cystosori (syn. sporosori) in soil, the DNA was extracted from a known number of cystosori and diluted with buffer to obtain a dilution series and a range of standards to quantify the amounts of $S$. subterranea DNA and express them as $S$. subterranea DNA equivalent. This method was able to detect $S$. subterranea cystosori with high sensitivity in water but sensitivity was reduced in the soil. Using a similar protocol with additional optimization, S. subterranea DNA was detected and quantified with greater sensitivity in large soil samples (Brierley et al. 2009). Although these methods work well in a research format, where investigators are interested in determining the femtograms or picograms of target DNA in a sample to study disease development, they are less useful when applying the technology in an agricultural setting, where it is important for producers to understand the information they receive. Additionally, the procedure of handling larger soil samples of $60 \mathrm{~g}$ or so complicates the management of soil samples and the procedure of quantification itself when large amounts of samples

Table 6. Spongospora subterranea sporosori levels quantified in commercial fields during 2017 and 2018 using quantitative real-time PCR

\begin{tabular}{|c|c|c|c|c|c|c|}
\hline \multirow[b]{2}{*}{ State } & \multirow[b]{2}{*}{ Total samples ${ }^{\mathbf{b}}$} & \multicolumn{2}{|c|}{$\begin{array}{l}\text { Soils tested } \\
\text { S. subterranea } \\
\text { positive }\end{array}$} & \multicolumn{3}{|c|}{$\begin{array}{c}\text { S. subterranea } \\
\text { sporosori levels }(\%)^{\mathrm{a}}\end{array}$} \\
\hline & & Number & Percent & Low & Moderate & High \\
\hline Colorado & 120 & 82 & 68 & 58 & 42 & $\cdots$ \\
\hline Nebraska & 32 & 1 & 3 & 100 & .. & $\ldots$ \\
\hline Michigan & 22 & 9 & 41 & 78 & 22 & $\ldots$ \\
\hline Maine & 109 & 99 & 91 & 46 & 52 & 2 \\
\hline Washington & 126 & 101 & 80 & 50 & 46 & 4 \\
\hline Idaho & 4 & 2 & 50 & $\ldots$ & 100 & $\ldots$ \\
\hline New York & 30 & 20 & 67 & 35 & 65 & $\ldots$ \\
\hline
\end{tabular}

${ }^{\text {a }}$ S. subterranea sporosori levels were calculated using the formula Normalized amount $=($ S. subterranea sporosori of each sample/EC of each sample $)$ $\times$ Average of total EC. Based on initial results, the $S$. subterranea categories were arbitrarily grouped as low $\left(<10^{2}\right.$ sporosori/g of soil $)$, moderate $\left(10^{2}\right.$ to $10^{4}$ sporosori/g of soil), and high ( $>10^{4}$ sporosori/g of soil).

b Total soil samples tested. are required to be processed. Potato producers have expressed concern that knowing the quantities of target DNA was not particularly useful to them because this is not the type of information with which they are familiar. For example, when producers send soil samples for fertility or pest evaluations, they receive results that tell them the level of nitrogen, phosphorous, or potassium in units that are relevant to their production system such as kilograms per hectare of a nutrient, number of nematode species per $500 \mathrm{~cm}^{3}$ of soil, or Verticillium spp. propagules per gram of soil. Our goal was to provide similar information for both potato producers and future research studies, and to develop risk assessment models for producers who are interested in knowing the actual levels of the powdery scab pathogen that are present in their soils and how these pathogen levels interact with specific cultivars that differ in susceptibility, similar to studies previously conducted (Brierley et al. 2013). To accomplish our goal, we spiked soil with a dilution series of $S$. subterranea sporosori ranging from 1 to 120,000 sporosori/g of soil and used the DNA extracted from the spiked soil as a range of standards to quantify the $S$. subterranea sporosori in soils from commercial fields. Results of the studies presented here demonstrate that the detection method for $S$. subterranea sporosori is highly sensitive and capable of detecting as few as 1 sporosorus/g of soil with consistently high qPCR efficiency (ranging from 94 to $99 \%$ ) and $R^{2}$ values of 0.98 to 0.99 . Based on initial results from qPCR, the soil levels of $S$. subterranea led us to arbitrarily establish categories as low $\left(<10^{2}\right.$ sporosori/g of soil $)$, moderate $\left(10^{4}\right.$ to $10^{2}$ sporosori/g of soil), and high ( $>10^{4}$ sporosori/g of soil). The producers were given not only the information about the actual number of $S$. subterranea sporosori per gram of soil but also the category of the field, depending on the level of $S$. subterranea.

Soil has been long recognized as one of the most difficult environments to work with for the efficient and effective detection and quantification of microorganisms due to its complex biological and chemical composition (Kageyama et al. 2003; Kuske et al. 1998; Wilson 1997). OM, fulvic and humic acids, and other physical properties make it an extremely challenging source for molecular detection of pathogens because a number of these factors can be powerful

Table 8. Detection and quantification of Spongospora subterranea sporosori in potting mix

\begin{tabular}{lccc}
\hline Source & $\begin{array}{c}\text { Total } \\
\text { samples } \\
\text { tested }\end{array}$ & S. subterranea-positive samples & $\begin{array}{c}\text { Mean } \\
\text { Number of } \\
\text { sporosori/g of } \\
\text { potting mix }^{\mathbf{a}}\end{array}$ \\
\hline A & 12 & 1 & 4.90 \\
B & 8 & 3 & 1.26 \\
C & 3 & 1 & 5.72 \\
\hline
\end{tabular}

${ }^{a}$ S. subterranea sporosori levels were calculated using the formula Normalized amount $=($ S. subterranea sporosori of each sample/EC of each sample $)$ $\times$ Average of total EC.

Table 7. Comparison of Spongospora subterranea sporosori per gram in commercial fields from different locations with or without normalizing the soil samples ${ }^{\mathrm{a}}$

\begin{tabular}{|c|c|c|c|c|c|c|c|}
\hline \multirow[b]{3}{*}{ Number } & \multirow[b]{3}{*}{ Location } & \multirow[b]{3}{*}{ Sample } & \multicolumn{5}{|c|}{ Sporosori/g of soil } \\
\hline & & & \multicolumn{2}{|c|}{ Nonnormalized samples ${ }^{b}$} & \multicolumn{2}{|c|}{ Normalized samples ${ }^{\mathrm{c}}$} & \multirow[b]{2}{*}{ Difference $^{d}$} \\
\hline & & & Number & Average & Number & Average & \\
\hline \multirow[t]{2}{*}{1} & Washington & Rep 1 & $32,496.2$ & $31,490.2$ & $33,102.6$ & $33,108.8$ & $1,618.6$ \\
\hline & $\ldots$ & Rep 2 & $30,484.2$ & $\ldots$ & $33,115.0$ & $\ldots$ & $\ldots$ \\
\hline \multirow[t]{2}{*}{2} & Maine & Rep 1 & $13,845.6$ & $13,511.1$ & $14,731.2$ & $14,760.0$ & $1,248.9$ \\
\hline & $\ldots$ & Rep 2 & $13,176.6$ & $\ldots$ & $14,788.8$ & $\ldots$ & $\ldots$ \\
\hline \multirow[t]{2}{*}{3} & Idaho & Rep 1 & $1,693.7$ & $1,660.8$ & $1,739.4$ & $1,735.1$ & 74.3 \\
\hline & $\ldots$ & Rep 2 & 1,628 & $\ldots$ & $1,730.8$ & $\ldots$ & $\ldots$ \\
\hline \multirow[t]{2}{*}{4} & New York & Rep 1 & 471.6 & 414.7 & 498.1 & 490.7 & 76 \\
\hline & $\ldots$ & Rep 2 & 357.8 & $\ldots$ & 483.4 & $\ldots$ & $\ldots$ \\
\hline
\end{tabular}

a $S$. subterranea sporosori per gram was normalized in soil samples by adding external control (EC) directly to the soil.

b $S$. subterranea sporosori levels were calculated based on cycle threshold values obtained from the standard curve and Bio-Rad CFX software, version 3.1

${ }^{\mathrm{c}} \mathrm{EC}$ (pUC19) was added at a concentration of $40 \mathrm{pg} / \mathrm{g}$ of soil prior to DNA extraction to normalize the data. S. subterranea sporosori levels were normalized using the formula Normalized amount $=($ S. subterranea sporosori of each sample/EC of each sample $) \times$ Average of total EC.

${ }^{\mathrm{d}}$ Difference in sporosori/g of nonnormalized and normalized soil samples. 
inhibitors of PCR (Kuske et al. 1998; Wilson 1997). Our second goal was to add a control to check the reliability of DNA extraction from soil. Currently, there are some published protocols available for quantifying S. subterranea in soil utilizing a control to confirm the DNA quality and qPCR amplification conditions and normalize the data (Balendres et al. 2018; Thangavel et al. 2015). In these studies, an "internal control" consisting of conserved mitochondrial cytochrome oxidase from the spiked potato DNA was amplified along with the $S$. subterranea internal transcribed space (ITS) sequence. The $S$. subterranea DNA concentration was then calculated using a standard curve generated from dilutions of plasmid DNA of $S$. subterranea containing the ITS sequence. In the present study, the standard curve was created by spiking the soil instead of using DNA, so that there was a uniform comparison between the external standards to create the standard curve and the samples where $S$. subterranea sporosori were quantified. For the first time, the EC was added directly to the soil spiked with $S$. subterranea sporosori to create a standard curve for quantification and to the soil samples with unknown $S$. subterranea sporosori numbers at a constant concentration. The $\mathrm{Ct}$ values of EC across the standard curve and the soil samples were considered for normalizing the data for $S$. subterranea quantification. The amount of EC added was at a comparatively lower concentration of $40 \mathrm{pg} / \mathrm{g}$ of soil consistently for all of the soil samples.

There have been some additional studies conducted to enhance the S. subterranea sporosori quantification in soil and, at the same time, test the sensitivity of qPCR data using different amounts of an $S$. subterranea gene inserted in the pGEM-T vector (Bittara et al. 2017; DeShields et al. 2018). In this approach, the 10-fold dilutions of the plasmid DNA were prepared, and the $\mathrm{Ct}$ values obtained were used to create a standard curve between the amounts of plasmid DNA and a known amount of $S$. subterranea resting spores in order to calculate the $S$. subterranea in other soil samples. In the studies reported here, we simplified the process by adding the EC at a very low concentration directly to soil samples prior to DNA extraction. The EC was coextracted with $S$. subterranea sporosori during DNA extraction. The method is very simple and minimizes the errors due to inconsistencies that might occur in separate reactions.

The data from this study indicated that the EC was successfully being coextracted with DNA from soil. We were aware that the EC, being a plasmid DNA, could extract and amplify at a different efficiency when compared with pathogen genomic DNA. Also, the naked DNA may extract more efficiently than cellular DNA. The current protocol normalizes the data based on the ratio of $\mathrm{EC} \mathrm{Ct}$ values of each sample and an average of EC Ct values of all the samples, which addresses the possibility of any discrepancies. Very consistent EC Ct values were observed throughout the independent experiments that were conducted in two separate laboratories using different soil types. To our knowledge, this is the first report of adding an EC directly to the soil and coextracting the DNA. This method was useful for normalizing the differences in the DNA extraction and qPCR amplification efficiency among different soil types that are assayed at the same time and among assays performed at different times. The efficiency and sensitivity of qPCR were compared among soil types collected from four different locations differing in their physical properties of $\mathrm{OM}, \mathrm{pH}$, and texture. The efficiency, sensitivity, and correlation of coefficient values among all of the soil types were found to be highly satisfactory. Additionally, the efficiency and sensitivity of the assay did not change regardless of whether a single or duplex qPCR (with the EC) was being performed. This makes the method highly robust and versatile in quantifying the $S$. subterranea sporosori in any type of soil.

It has been observed that the qPCR is inhibited if the OM in the sample is too high (Watson and Blackwell 2000). Although the $S$. subterranea sporosori were successfully quantified in soil samples with higher OM using this protocol, we were pleased at how effective the qPCR method was when working with samples with extremely high OM such as the potting mix used frequently in greenhouse experiments. Despite this success, we feel it is advisable to understand the level of OM of any prospective soils to be assayed if the EC and $S$. subterranea are not amplified during qPCR in order to avoid falsenegative results. The amplification of EC indicates that there is no inhibition in the qPCR and the results of the soil assay mean that either the soil is free of $S$. subterranea or below the level of detection of 1 sporosorus/g of soil. There were some soil samples where both the S. subterranea and EC were not amplified initially. This gave us an indication that the DNA extracted from soil requires further elimination of PCR inhibitors from the extraction mixture.

While testing soil samples for $S$. subterranea from various commercial fields across the country, it was observed that most of the soils tested consisted of sporosori in the range of $8.5 \times 10^{1}$ to $5.5 \times$ $10^{4}$ sporosori/g of soil. A study conducted on investigating the relationship between $S$. subterranea soil inoculum level, host resistance, and powdery scab on potato tubers in the field indicated that the disease incidence and intensity were significantly greater in plots with increasing levels of inoculum (Brierley et al. 2013). Regardless of their maturity stage, sporosori can germinate in presence of a favorable plant or environmental stimuli and infect the plant, causing powdery scab (Balendres et al. 2017; Harrison et al. 1997; Merz 2008). It will be important for research to be conducted in the United States to understand the relationship of $S$. subterranea soil inoculum and the reaction of North American potato cultivars so that the potato industry can make informed decisions on how to manage powdery scab. The qPCR method reported here can be used to facilitate this type of risk assessment research.

It is important for potato growers to be aware of the levels of soilborne pathogens in their fields as a part of their integrated crop management plan. In this specific case, this type of information can assist growers to avert significant crop losses due to the presence of the powdery scab pathogen. These data also provide an essential piece of information regarding the potential risk of powdery scab disease incidence, perhaps allowing growers to avoid subsequent infection by PMTV in those potato-growing regions where this pathogen is known to exist. With the development of a robust and sensitive method for quantifying the $S$. subterranea sporosori from soil that utilizes a universal EC incorporated into the protocol, we believe we have provided the initial first step in the development of a multiplex qPCR for detecting and quantifying multiple soilborne pathogens such as $C$. coccodes and $V$. dahliae in soil with an inclusion of an EC to normalize the data which is added directly to the soil before DNA extraction.

\section{Acknowledgments}

We thank D. Peterson and R. Benz for their valuable assistance.

\section{Literature Cited}

Arif, M., Torrance, L., and Reavy, B. 1995. Acquisition and transmission of potato mop-top furovirus by a culture of Spongospora subterranea $\mathrm{f}$. sp. subterranea derived from a single cystosorus. Ann. Appl. Biol. 126:493-503.

Balendres, M. A., Clark, T. J., Tegg, R. S., and Wilson, C. R. 2018. Germinate to exterminate: Chemical stimulation of Spongospora subterranea resting spore germination and its potential to diminish soil inoculum. Plant Pathol. 67:902-908.

Balendres, M. A., Tegg, R. S., and Wilson, C. R. 2017. Resting spore dormancy and infectivity characteristics of the potato powdery scab pathogen Spongospora subterranea. J. Phytopathol. 165:323-330.

Bell, K. S., Roberts, J., Verrall, S., Cullen, D. W., Williams, N. A., Harrison, J. G., Toth, I. K., Cooke, D. E. L., Duncan, J. M., and Claxton, J. R. 1999. Detection and quantification of Spongospora subterranea f. sp. subterranea in soils and on tubers using specific PCR primers. Eur. J. Plant Pathol. 105:905-915.

Bilodeau, G. J., Koike, S. T., Uribe, P., and Martin, F. N. 2012. Development of an assay for rapid detection and quantification of Verticillium dahliae in soil. Phytopathology 102:331-343.

Bittara, F. G., Secor, G. A., and Gudmestad, N. C. 2017. Chloropicrin soil fumigation reduces Spongospora subterranea soil inoculum levels but does not control powdery scab disease on roots and tubers of potato. Am. J. Potato Res. 94:129-147.

Bittara, F. G., Thompson, A. L., Gudmestad, N. C., and Secor, G. A. 2016. Field evaluation of potato genotypes for resistance to powdery scab on tubers and root gall formation caused by Spongospora subterranea. Am. J. Potato Res. 93:497-508.

Braithwaite, M., Falloon, R. E., Genet, R. A., Wallace, A. R., Fletcher, J. D., and Braam, W. F. 1994. Control of powdery scab of potatoes with chemical seed tuber treatments. N. Z. J. Crop Hortic. Sci. 22:121-128.

Braselton, J. P. 2001. Plasmodiophoromycota. Pages 81-91 in: The Mycota VII, Part A, Systematics and Evolution. D. J. McLaughlin, E. G. McLaughlin, and P. A. Lemke, eds. Springer-Verlag, Berlin, Heidelberg, Germany.

Brierley, J. L., Stewart, J. A., and Lees, A. K. 2009. Quantifying potato pathogen DNA in soil. App. Soil Ecol. 41:234-238. 
Brierley, J. L., Sullivan, L., Wale, S. J., Hilton, A. J., Kiezebrink, D. T., and Lees, A. K. 2013. Relationship between Spongospora subterranea f. sp. subterranea soil inoculum level, host resistance and powdery scab on potato tubers in the field. Plant Pathol. 62:413-420.

Carnegie, S. F., Choiseul, J. W., and Roberts, A. M. I. 2003. Detection of Colletotrichum coccodes and Helminthosporium solani in soils by bioassay. Plant Pathol. 52:13-21.

Christ, B. J. 2001. Powdery scab. Pages 35-36 in: Compendium of Potato Diseases, 2nd ed. W. R. Stevenson, R. Loria, G. D. Franc, and D. P. Weingartner, eds. American Phytopathological Society, St. Paul, MN, U.S.A.

Christ, B. J., and Weidner, R. J. 1988. Incidence and severity of powdery scab on potatoes in Pennsylvania. Am. Potato J. 65:583-588.

Cullen, D. W., Lees, A. K., Toth, I. K., and Duncan, J. M. 2001. Conventional PCR and real-time quantitative PCR detection of Helminthosporium solani in soil and on potato tubers. Eur. J. Plant Pathol. 107:387-398.

Cullen, D. W., Lees, A. K., Toth, I. K., and Duncan, J. M. 2002. Detection of Colletotrichum coccodes from soil and potato tubers by conventional and quantitative real-time PCR. Plant Pathol. 51:281-292.

Daniell, T. J., Davidson, J., Alexander, C. J., Caul, S., and Roberts, D. M. 2012. Improved real-time PCR estimation of gene copy number in soil extracts using an artificial reference. J. Microbiol. Methods 91:38-44.

Dauch, A. L., Watson, A. K., Seguin, P., and Jabaji-Hare, S. H. 2006. Real-time PCR quantification of Colletotrichum coccodes DNA in soils from bioherbicide field release assays, with normalization for PCR inhibition. Can. J. Plant Pathol. 28:42-51.

De Boer, R. F. 2000. Research into the biology and control of powdery scab of potatoes in Australia. Pages 79-83 in: Proc. First Eur. Powdery Scab Workshop, Aberdeen, Scotland. U. Merz and A. K. Lees, eds. http:// www.spongospora.ethz.ch/EUworkshop/proceedings.html

de Nazareno, N. R. X., and Boschetto, N. 2002. Seed tuber transmission of Spongospora subterranea. Fitopatol. Bras. 27:224.

DeSheilds, J. B., Bomberger, R. A., Woodhall, J. W., Wheeler, D. L., Moroz, N., Johnson, D. A., and Tanaka, K. 2018. On-site molecular detection of soil-borne phytopathogens using a portable real-time PCR system. J. Vis. Exp. 132:1-11.

Domfeh, O., and Gudmestad, N. C. 2016. Effect of soil moisture management on the development of Potato mop top virus-induced tuber necrosis. Plant Dis. 100: 418-423.

Falloon, R. E. 2008. Control of powdery scab of potato: Towards integrated disease management. Am. J. Potato Res. 85:253-260.

Falloon, R. E., Genet, R. A., Wallace, A. R., and Butler, R. C. 2003. Susceptibility of potato (Solanum tuberosum) cultivars to powdery scab (caused by Spongospora subterranea f. sp. subterranea), and relationships between tuber and root infection. Australas. Plant Pathol. 32:377-385.

Falloon, R. E., Wallace, A. R., Braithwaite, M., Genet, R. A., Nott, H. M., Fletcher, J. D., and Braam, W. F. 1996. Assessment of seed tuber, in-furrow, and foliar chemical treatments for control of powdery scab (Spongospora subterranea f. sp. subterranea) of potato. N. Z J. Crop Hortic. 24:341-353.

Frostegard, A., Courtois, S., Ramisse, V., Clerc, S., Bernillon, D., Gall, F. L., Jeannin, P., Nesme, X., and Simonet, P. 1999. Quantification of bias related to the extraction of DNA directly from soils. Appl. Environ. Microbiol. 65:5409-5420.

Grandy, A. S., Porter, G. A., and Erich, M. S. 2002. Organic amendment and rotation crop effects on the recovery of soil organic matter and aggregation in potato cropping systems. Soil Sci. Soc. Am. J. 66:1311-1319.

Gudmestad, N. C., Taylor, R. J., and Pasche, J. S. 2007. Management of soilborne diseases of potato. Australas. Plant Pathol. 36:109-115.

Harrison, J. G., Searle, R. J., and Williams, N. A. 1997. Powdery scab disease of potato-a review. Plant Pathol. 46:1-25.

Jones, R. A. C., and Harrison, B. B. 1969. The behavior of potato mop-top virus in soil, and evidence for its transmission by Spongospora subterranea (Wallr.) Lagerh. Ann. Appl. Biol. 63:1-17.

Kageyama, K., Komatusu, T., and Suga, H. 2003. Refined PCR protocol for detection of plant pathogens in soil. J. Gen. Plant Pathol. 69:153-160.

Kuske, C. R., Banton, K. L., Adorada, D. L., Stark, P. C., Hill, K. K., and Jackson, P. L. 1998. Small-scale DNA sample preparation method for field PCR detection of microbial cells and spore in soil. Appl. Environ. Microbiol. 64:2463-2472.

Lahert, H., and Kavanagh, J. A. 1985. The fine structure of the cystosorus of Spongospora subterranea, the cause of powdery scab of potato. Can. J. Bot. 63:2278-2282
Letham, D. B., Murison, J. A., Francis, A., and Kennedy, P. G. 1989. Occurrence of Spongospora subterranea in an area of improved pasture at Barrington Tops, New South Wales. Australas. Plant Pathol. 18:17-19.

Merz, U. 1989. Infectivity, inoculum density and germination of Spongospora subterranea resting spores: A solution-culture test system. EPPO Bull. 19:585-592.

Merz, U. 2008. Powdery scab of potato-Occurrence, life cycle and epidemiology. Am. J. Potato Res. 85:241-246.

Merz, U., and Falloon, R. E. 2009. Review: Powdery scab of potato-Increased knowledge of pathogen biology and disease epidemiology for effective disease management. Potato Res. 52:17-37.

Merz, U., Jaquiery, P.-Y., Zala, M., and Keiser, A. 2006. Powdery scab of potato: Epidemiological and molecular aspects of a field population of Spongospora subterranea f. sp. subterranea. Page 60 in: Proc. 4th Australas. Soilborne Dis. Symp., Queenstown, New Zealand.

Nakayama, T., Horita, M., and Shimanuki, T. 2007. Spongospora subterranea soil contamination and its relationship to severity of powdery scab on potatoes. J. Gen. Plant Pathol. 73:229-234

Neuhauser, S., Bulam, S., and Kirchmair, M. 2010. Plasmodiophorids: The challenge to understand soil-borne, obligate biotrophs with a multiphasic life cycle. Pages 51-78 in: Molecular Identification of Fungi. Y. Gherbawy and K. Viogt, eds. Springer-Verlag, Berlin, Germany.

Neuhauser, S., Kirchmair, M., Bulman, S., and Bass, D. 2014. Cross-kingdom host shifts of phytomyxid parasites. BMC Evol. Biol. 14: Article 33.

Nicot, P. C., and Rouse, D. I. 1987. Relationship between soil inoculum density of Verticillium dahliae and systemic colonization of potato stems in commercial potato fields over time. Phytopathology 77:1346-1355.

Okubara, P. A., Schroeder, K. L., and Paulitz, T. C. 2005. Real-time polymerase chain reaction: Applications to studies on soilborne pathogens. Can. J. Plant Pathol. 27:300-313.

Qu, X. S., and Christ, B. J. 2006. The host range of Spongospora subterranea f. sp. subterranea in the United States. Am. J. Potato Res. 83:343-347.

Qu, X. S., Wanner, L. A., and Christ, B. J. 2011. Multiplex real-time PCR (TaqMan) assay for the simultaneous detection and discrimination of potato powdery and common scab diseases and pathogens. J. Appl. Microbiol. 110: 769-777.

Robe, P., Nalin, R., Capellano, C., Vogel, T. M., and Simonet, P. 2003. Extraction of DNA from soil. Eur. J. Soil Biol. 39:183-190.

Schena, L., Nigro, F., and Ippolito, A. 2004. Real-time PCR detection and quantification of soilborne fungal pathogens: The case of Rosellinia necatrix, Phytophthora nicotianae, $P$. citrophthora, and Verticillium dahliae. Phytopathol. Mediterr. 43:273-280.

Singleton, L. L., Mihail, J. D., and Rush, C. M. 1992. Methods for Research on Soilborne Phytopathogenic Fungi. American Phytopathological Society, St. Paul, MN, U.S.A.

Sparrow, L. A., Rettke, M., and Corkrey, S. R. 2015. Eight years of annua monitoring of DNA of soil-borne potato pathogens in farm soils in south eastern Australia. Australas. Plant Pathol. 44:191-203.

Tebbe, C. C., and Vahjen, W. 1993. Interference of humic acids and DNA extracted directly from soil in detection and transformation of recombinant DNA from bacteria and a yeast. Appl. Environ. Microbiol. 59:2657-2665.

Thangavel, T., Tegg, R. S., and Wilson, C. R. 2015. Monitoring Spongospora subterranea development in potato roots reveals distinct infection patterns and enables efficient assessment of disease methods. PLoS One 10 e0137647.

van de Graaf, P., Lees, A. K., Cullen, D. W., and Duncan, J. M. 2003. Detection and quantification of Spongospora subterranea in soil, water and plant tissue samples using real-time PCR. Eur. J. Plant Pathol. 109:589-597.

Wale, S. J. 2000. Summary of the session on national potato production and the powdery scab situation. Pages 3-9 in: Proc. First Eur. Powdery Scab Workshop, Scottish Agricultural College, Aberdeen, Scotland. U. Merz and A. K. Lees, eds. Wallroth, F. W. 1842. Der Knollenbrand der Kartoffel. Linnea 16:332.

Watson, R. J., and Blackwell, B. 2000. Purification and characterization of a common soil component which inhibits the polymerase chain reaction. Can. J. Microbiol. 46:633-642.

Wilhelm, J., and Pingoud, A. 2003. Real-time polymerase chain reaction ChemBioChem 4:1120-1128.

Wilson, I. G. 1997. Inhibition and facilitation of nucleic acid amplification. Appl Environ. Microbiol. 63:3741-3751. 